\title{
Organizasyonlarda Sinizm ile Sanal Kaytarma Davranışı İlişkisinde Çalışan Yaşının Düzenleyici Etkisi
}

\author{
Edip ÖRÜCÜ* Itır HASIRCI **
}

\begin{abstract}
$\ddot{O} Z$
Bu araştırmanın amacı, örgütsel sinizmin sanal kaytarma davranışı üzerindeki etkisinde örgüt çalışanlarının yaş düzeylerinin hızlandırıcı etkisini belirlemektir. Araştırmanın evrenini Balıkesir'in Bandirma ilçesinde bulunan bir kamu iktisadi teşebbüsünde çalışmakta olan 350 kişi oluşturmaktadır. 350 kişiden 200 işgören ile bir anket çallşması gerçekleştirilmiş olup bu anketlerden 31 tanesi uygun görülmediği için elenmiştir ve geriye kalan 169 çalışandan elde edilen anketle analizler yapılmıştır. Katılımcıların \%35,5'i erkek, \%64,5'i kadın, yaş ortalamaları \% 32-38 yaş arası $(33,1)$ ve lisans mezunu $(\% 42,6)$ 'dır. Elde edilen verilerin analizi için regresyon analizi, korelasyon analizi, faktör analizi yapılmıştır. Yapılan analizler neticesinde örgütsel sinizmin sanal kaytarma davranışı üzerindeki etkisinde çalışanların yaş düzeylerinin hızlandırıcı etkisinin olduğu belirlenmiştir. Çalışmanın sonunda sonuçlar yorumlanıp, tartışılmıştır.
\end{abstract}

Anahtar Kelimeler: Sanal Kaytarma, Örgütsel Sinizm, Tükenmişlik.

JEL Sinıflandırması: D23, O15, M54

\section{The Moderator Effect of Employee Age on the Relationship Between Cynicism and Cyberloafing Behaviour in Organizations}

\begin{abstract}
The aim of this research is to determine the moderating effect of age levels of employees in the impact of organizational cynicism on cyberloafing behaviour. The universe of the research consists of 350 people working in a state-owned enterprise located in the Bandirma District of Ballkesir. A survey was conducted with 200 employees from 350 people, 31 of which were eliminated because they were deemed unsutiable so the survey was analyzed from the remaining 169 employees. $35,5 \%$ of the respondents were male, $64,5 \%$ were female, with an avarage age of $32-38$ years $(33,1 \%)$ an da bachelor's degree (42,6\%). Regression analysis, correlation analysis, factor analysis were performed for the data. As a result of the analysis, it was determined that the effect of organizational cynicism on cyberloafing behaviour had an moderating effect on the age levels of employees. At the end of the study, the results were interpreted and discussed.
\end{abstract}

Key Words: Cyberloafing, Organizational Cynicism, Burnout.

JEL Classification: D23, O15, M54

\section{GíRiş}

$\mathrm{Bu}$ araştırmanın amac1, örgütsel sinizmin sanal kaytarma davranışı üzerindeki etkisinde örgüt çalışanlarının yaş düzeylerinin hızlandırıcı etkisini belirlemektir. Sanal kaytarma kavramı internet ağının ve bilgisayarların iş amaçlı kullanımlarının haricinde kişisel amaçlar için kullanılmasıdır. Örgütlerde internet

\footnotetext{
*Prof. Dr., Bandırma Onyedi Eylül Üniversitesi İ.İ.B.F., İşletme Bölümü. eorucu@bandirma.edu.tr, ORCID Bilgisi: 0000-0002-3301-7496

** Doktora Öğrencisi, Bandırma Onyedi Eylül Üniversitesi Sosyal Bilimler Enstitüsü, İşletme Bölümü, itir8686@gmail.com,, ORCID Bilgisi: 0000-0002-5449-2640
} 
ağının kullanımı hem çalışanlar açısından büyük kolaylıklar sağlamakta hem de iş yükünün azaltılması hususunda yardımcı olmaktadır. Fakat internet ağının kullanımında son y1llarda gittikçe artan bir suistimal etme durumu meydana gelmektedir. Özellikle akıllı telefonlar, tabletler vb. bu niyetle kullanıldığında süreç kontrol edilemez bir hal almaya başlamıştır. Sanal kaytarma sosyolojik boyutlarından ziyade iş yerlerinde ciddi maliyet kayıplarına da neden olan bir kavramdır. Mobil aygıtlar açısından bir kullanım politikası belirlenmediği müddetçe sanal kaytarma faaliyetleri içinden çıkılamaz bir hale gelmeye devam edecektir ve bu kontrolsüz güç işletme yararına kullanılmadıkça bir güç olmaktan çıkacak ve yöneticiler için tehditlere, örgütler için de verimlilik kayıplarına neden olacaktır (Örücü ve Y1ldı, 2014: 99-114).

Türk Dil Kurumu sözlüğünde insanın erdem ve mutluluğa tamamen kendi çabalarıyla ulaşabileceğini savunan Antisthenes'in öğretisi sinizm (kinizm), Cambridge sözlüğ̈̈nde bireylerin samimiyetten uzak ve sadece kendi menfaatlerini düşündüklerini savunan bir kavram olarak tanımlanmıştır. Sinizm kavramının tarihi Diyojen'le vücut bulmuştur. Diyojen'in gündüz vakti el feneriyle dolaşarak dürüst bir insan arıyorum demesi sinizm kavramının somutlaşmasını sağlamıştır (Sinan ve Kavas, 2016: 1211-1212). Başkalarının davranışlarından hoşlanmama ve onlara güvenmeme şeklinde tanımlanan sinizm bireyde hayal kırıklı̆̆1, umutsuzluk, hor görme, bıkkınlık gibi kavramlarla da açıklanabilir (Bateman vd. , 1992: 758-772). $\mathrm{Bu}$ demektir ki sinik bireyler sürekli karşısındakini eleştiren, zor beğenen, aşağılayan ve kusur bulan davranışlar sergilemektedir. Literatür incelendiğinde örgütsel sinizm davranışlarının sanal kaytarmayı arttırdığı görülmektedir. Sinik davranışlar kişinin kendi özelliklerinden veya çalıştığı örgütün özelliklerinden oluşabilmektedir (Eaton, 2000). İki değişken arasındaki ilişkiyi ve çalışanların yaşları ile ilişkisini inceleyen ilk çalışma olacağı için bu çalışmanın literatüre önemli katkılar sağlaması beklenmektedir. Çalışmanın bundan sonraki bölümlerinde konu ile ilgili yapılmış geçmiş çalışmalar özetlenmekte, daha sonra yöntem, evren, örneklem ve bulgular ile elde edilen sonuç verilmektedir.

\section{KAVRAMSAL ÇERÇEVE}

\section{A. Sanal Kaytarma}

İnsanlar diğer bireylerin işlerini yapmaya başladıklarından itibaren işle ilgili sıkıntılardan uzaklaşmak için çalışma esnasında kaytarma yollarına başvurmaya başlamışlardır. Günümüzde teknolojinin gelişmesi ile beraber bu kaytarma davranışları sanal ortamda gerçekleştirilmektedir. Sanal kaytarma sapkın bir örgütsel davranış olarak kabul edilmekle beraber baştan çıkarıcı ve kullananları cezbedici bir hal almaya devam etmektedir. Bu durumda örgütler için üzerinde durulmas1 gereken bir konu haline gelmektedir (Ünal vd., 2015: 518-519).

Genel bir tanım olarak sanal kaytarma, bireylerin çalıştıkları kurumun internet ağını çalışma süreleri dâhilinde kendi amaçları için kullanmalarıdır (Lim, 2002: 675). Diğer bir tanımıyla sanal kaytarma, bireylerin iş ortamlarında çalıştıkları kurumun onlara sağladıkları internet bağlantısı ve e-posta olanaklarını bireysel ihtiyaçları için kullanmalarıdır (Bock ve Ho, 2009: 124-138). Kişiler sanal kaytarma ile çalışma saatleri içerisinde, yapmaları gereken işler dışında internet 
ağlarından faydalanmaktadırlar. Sanal kaytarma davranışları bilinçli olarak yapmalarının yanı sıra çalışma süreleri dâhilinde ve kişisel amaçları için gerçekleştirmektedirler (Lim, 2002: 677-691).

Ancak sanal kaytarma sadece bireyin çalıştığ 1 kurumun internet olanaklarından faydalanması ile gerçekleşmez. Birey kendi internet ağını da çalışma süresi içerisinde şahsi menfaatleri için kullanıyorsa bu durum da sanal kaytarma davranışı olarak adlandırılır ve bu davranış iş dışı faaliyetleri kapsar (Karataş, 2017: 2323-2335). Sanal kaytarma kavramı Türk literatürüne ilk defa Özkalp, Aydın ve Tekeli (2012) tarafından yapılan çalışma ile girmiştir. Çalışanları bu davranışı sergilemeye iten dış kontrol odaklılık, örgütsel adalet algısı, sosyal kolaylaştırma vb. faktörler de bulunmaktadır. Tüm bu faktörler de iş yerlerinde verimlilik kaybı, erteleme davranışı gibi olumsuz sonuçları doğurmaktadır (Yıldız ve Y1ldiz, 2015: 3-10).

Uluslararası literatüre cyberloafing, cyberloading gibi kavramlarla yerleşen sanal kaytarma Türkçe'de siber kaytarma ve siber aylaklık gibi terimlerle karşılık bulmaktadır. İşle alakası olmayan bilgisayar kullanımı, sapkın internet kullanımı, iş internetinin veya şahsi internetin kötü amaçlarla kullanımı, internete bağımlı olma sanal kaytarma davranışı örnek olarak gösterilebilir. Bu örneklerin haricinde online alışveriş yapmak, sosyal medyada gezinmek, iş arayışında olmak, sanal oyunlar oynamak, kişisel e-postalarla meşgul olmak, müzik indirmek de sanal kaytarma davranışı olarak adlandırılır. Çalışanlar bu davranışlarıyla iş esnasında harcamaları gereken performanslarını bu tarz faaliyetlerle azaltmaktadırlar. $\mathrm{Bu}$ durumda işgören verimliliğinin düşmesine yol açan bir davranıştır (Kerse vd., 2016: 102-120).

Günümüzde internet kullanımının artması ve bu kullanımın iş yerlerinde de sağlanması dolayısıyla çalışanların çalıştıkları kurumlarda internet serbestliği durumlarına belirli programlarla kısıtlamalar getirilmiştir. Kurumlar tarafindan yaşanabilecek olası zor durumlara karşı özel yazılım programları geliştirmiştir. Fakat bu programlar gerçekten belli başlı sitelere girmeye ihtiyacı olan çalışanlara da zarar vermektedir. Ayrıca iş yerinde sıkı internet kullanımı yasağı uygulaması çalışanlar üzerinde olumsuz etkiler yaratmakta, çalışmakta oldukları kuruma dair memnuniyetsizlik duymalarına neden olmaktadır (Yağc1 ve Yüceler, 2016: 534$535)$.

Demografik özellikler literatürde bulunan sanal kaytarma davranışlarında genellikle kontrol değişkeni olarak kullanılmıştır. Bunlar cinsiyet, ırk, eğitim, yaş, gelir, iş yerindeki konumu vb. şeklinde sıralanabilir. Yazarlar çalışmalarında kadınların erkeklerden ziyade daha az sanal kaytarma davranışı gösterdiklerini, gençlerin yaşlılara göre daha fazla internet kullandıklarını, çalışma süresi arttıkça da sanal kaytarma davranışlarının da arttığını vurgulamışlardır (Kaplan ve Çetinkaya, 2014: 29-36).

\section{B. Sanal Kaytarma Tipleri}

Anandarajan vd. (2004) sanal kaytarma tiplerini dört türde değerlendirmiştir. Bunlar eğlence maksatlı, belirsiz, zararlı ve bireysel öğrenme şeklindedir. Blanchard ve Henle (2008) ise sanal kaytarma tiplerini kısa süreli 
internet sitelerini ziyaret etme ve önemli sanal kaytarma olarak iki şekilde incelemiştir. Önemsiz sanal kaytarma davranışı gerçekleştiren işgörenler bu durumun çalıştıkları işletmeye zarar vermeyeceğini düşünmektedirler. Fakat önemli sanal kaytarma davranışı gerçekleştirenler ise sonuçların kendilerine ve çalıştıkları işletmeye zarar verebileceğinin farkındadırlar. Fakat bu düşünceye rağmen sanal kaytarma davranışını gerçekleştirmeye devam etmektedirler (Yıldız vd. , 2015: 57). Robinson ve diğerleri (1995) sanal kaytarma davranışı majör ve minör olmak üzere ikiye ayırarak incelemiştir. Çalışanın maillerini kontrol etmesi minör sanal kaytarma davranışı iken, sanal oyunlar oynaması ise majör sanal kaytarma davranışına örnek olarak verilebilir. Sanal kaytarma davranışlarının nedenleri Facebook, Instagram gibi internet sitelerinin popüler olmasıdır. Önceleri çalışma saatleri dâhilinde anlık mesajlaşmalar bile uygunsuz görülürken günümüzde çalışanlar bu sosyal medya ağlarına rahatlıkla mesai saatlerinde girmektedirler (Ulusoy ve Benli, 2017: 925).

Doorn (2011) çalışanların şu dört faktör sebebiyle sanal kaytarma gerçekleştirebileceğini savunmuşlardır (Doorn, 2011: 22):

Kişisel Gelişim: İşgörenlerin sanal kaytarmayı kendi gelişimlerini sağlamak amacıyla yapmasıdır. İşgörenler internet ortamında kişisel gelişimlerini sağlamak amacıyla gezinirken aynı zamanda streslerini azaltırlar ve daha farklı bilgiler edinirler. Dolayısıyla daha eğitimli ve bilgili bireyler haline gelirler.

Yenilenme: Çalışanın sağlığı ile alakalı olan bu olgunun örgüt ve çalışan üzerinde olumlu etkileri mevcuttur.

Suistimal: Çalışanın işini boşlamasıdır. Örneğin; çalışan maddi bir kazanç elde etmek amacıyla internete giriyorsa bu suistimal davranışıdır. Bu tür davranışlar elbette olumsuz olarak kabul edilmektedir.

Alışkanlık: Bir diğer adıyla internet bağımlılı̆̆ıdır ve psikolojik olarak ciddi bir vakadır. Alkol, madde bağımlıları gibi değerlendirilmekle beraber problemli bir davranış olarak kabul edilmektedir.

\section{C. Örgütsel Sinizm}

Bu felsefeye göre bireyler ahlaki ve sosyal değerleri reddederler ve doğanın kanunlarına göre yaşamlarını sürdürürler. Örneğin, Diagones hayatını bir fiçının içinde geçirmiş ve kendisini toplumsal gerekliliklerden arındırmıştır (Kalağan ve Güzeller, 2010: 84-96). Sinizm, kişilerin yaşadıkları toplumda gelişen olaylara karşı olumsuz bir bakış açısı sergilemeleri ve kötümser mizaca sahip olmalarıdır. Yani kişi kendi menfaatleri için diğer insanları bir araç olarak görür. Sinik bireyler samimiyete ve iyi niyete inanmamakla birlikte sürekli kusur bulur ve çevrelerini eleştirirler (Ada ve Yarım, 2017: 69-83). Örgütsel sinizm çalışanların bilincinde oldukları kötümser gizli niyetler hakkındaki düşüncelerini kendi çıkarlarını korumak veya arttırmak için idare etmeleridir. Dolayısıyla sinizm bireylerin çıkarcı davranışlarına olan inancın eğilimidir.

Vice'a (2011) göre sinizm, uyuşmazlık, güven eksikliği ve şüphe duyma gibi kavramların bir araya gelmesinden oluşmaktadır. Bu demektir ki sinizm kişilerin davranışlarının sadece çıkar ilişkisi üzerine kurulu olduğu bir kavramdır (Vice, 2011: 169-184). İşgörenler beklentilerinin karşlanmaması durumunda 
çalıştıkları örgüte yönelik sinik tavırlar sergilerler ve bu durum bir süre sonra işgören için psikolojik ve sinirsel bozukluk gibi olumsuz ruhsal problemlere yol açabilir. Bu olumsuz ruhsal durumları takiben bireyde uykusuzluk, depresyon, duygusal çökme, öfke, hayal kırıklığı yaşama, kırgınlık gibi negatif davranışlar da gözlenebilir (Costa ve Zonderman, 1986, 283-285).

Literatürde örgütsel sinizm ile ilgili farklı kavramsal açıklamalar mevcuttur. Bunlardan bazıları şu şekildedir:

En çok karşılaşılan tanım Dean'in tanımıdır. Dean (1998) örgütsel sinizm kavramını işgörenin çalıştığı örgüte karşı negatif duygular beslemesi, örgütün bütünlükten yoksun olduğuna inanması ve tüm bu duygularla birlikte kendisinin de aşağılayıcı duygu ve tavırlar sergilemesi hali şeklinde tanımlamıştır (Dean, 1998: 345-370). Dean'e göre örgütsel sinizm, biliş, duygu ve davranış kavramlarıyla ele alınmıştır. Bilişsel boyutta işgören çalıştığı örgütteki bireylerin dürüst olmadığını düşünmektedir. Duygusal boyutta işgörenler çalıştıkları örgütü küçümseyici ve kızgın tavırlar sergilerler. Davranışsal boyutta ise işgörenler, çalıştıkları örgütte gelişen olaylar hakkında sürekli karamsar tahminler yaparlar. Sinik tavırlarını bastırmak adına sürekli alaycı davranışlar sergilerler. Örneğin; çalıştıkları örgütün amaçları ile alay ederler, yorumları da alaycı olabilir (Karacaoğlu ve İnce, 2012: 78-79). Stern vd (1990) örgütsel sinizm için, örgütlerin çalışanlarını önemsemediklerini ve birçok işin çalışanların bağlılığına layık olmadığını belirtmiştir (Stern vd. , 1990: 271). Wilkerson (2008) örgütsel sinizmi bireyin çalıştı̆̆ 1 örgüte karşı geliştirdiği negatif tutumlar şeklinde tanımlamaktadır (Wilkerson, 2008: 2274-2282). Naus (2007) örgüt tarafından atılan adımlarla ilgili olumsuz ve kötü düşüncelere karşı kendini savunma hali ve iş çevresinde itibar kazanabilmek şeklinde sinizmi tanımlamaktadır (Naus, 2007: 685-689). Abraham (2000) örgütsel sinizmi, işgörenlerin kişisel değerleri ile çalıştıkları kurumun değerleri arasında bir uyumun bulunmaması durumu olarak tanımlamıştır (Abraham, 2000: 269-292). Arslan (2012) çalıştığı örgütte sinik tutumları deneyimleyen işgörenlerin liderlerine güvenmediklerini, fursat bulsalar sömürüleceklerini, ödül dağılımının adil bir şekilde yapılmadığını ve örgütsel faaliyetlerin samimi ve dürüst olmadığını belirtmiştir (Arslan, 2012: 14-25).

Örgütsel sinizm üç boyuttan meydana gelmektedir (Erbaş1 ve Zaganjori, 2017: 41-53):

\footnotetext{
Örgütsel bütünlüğ̈̈n olmadığına dair inanç,

- $\quad$ Örgüte karşı negatif bir tutum sergilemek,

- Küçümseme.

D. Örgütsel Sinizmin Sonuçları
}

Bireysel Açıdan Sonuçları

- Davranışsal Sonuçlar (Duyarsızlaşma): Bu durum beraberinde işten ayrılma, performans düşüklüğü ve verimlilikte düşüşlere yol açabilir. Duyarsızlaşma durumu, işgörenin hizmet sunduğu kişilere karşı duygusuz tavırlar sergilemesi ile meydana gelmektedir. Böylece işgören karşısında bulunan kişilere karşı tamamen duygusuz, alaycı ve katı bir tutum sergilemeye başlamaktadır. Ayrıca işgörenler hem çalıştıkları örgüte karşı hem de hizmet sundukları kişilere 
karşı umursamaz ve mesafeli yaklaşmakta, bu durumdan da herhangi bir rahatsızlık duymamaktadirlar.

- $\quad$ Psikolojik Sonuçlar (Duygusal Tükenme). Duygusal tükenme yaşayan işgörenler kendilerini yorgun, yıpranmış hissederler ve eski çalışma yıllarında gösterdiği gayreti sergileyemediğini düşünerek kendisini engellenmiş ve gergin hissederler. Bu durumda beraberinde işe gitme zorunluluğunu doğurur ve işgörende bu zorunluluk endişe verici bir hal almaya başlar.

Örgütsel Sonuçlar

- $\quad$ İş Tatmini: İş tatmini işgörenin belirli bir işe karşı olumlu duygusal tepkilerinin tümüdür. $\mathrm{Bu}$ durumda iş tatmini ile işgörenin işe devamlılığının artması, işini çekici görmesi ve verimliliğinin yüksek olması beklenmektedir. İşgörenlerin sinizm dereceleri yüksek olduğunda belirtilen iş tatminlerinde düşme meydana gelmektedir. Sinizme sahip olan işgörenler çalıştıkları örgütteki çalışma arkadaşlarına karşı, çalıştıkları örgüte karşı iş tatminsizlikleri yaşamaktadırlar.

- $\quad$ Örgütsel Bağlılık: Çalıştıkları örgüte bağlı olan işgörenler örgütün başarısı için ellerinden gelenin daima fazlasını yapıp, fazladan görev davranışları sergileyeceklerdir. Böylece çalıştıkları örgütün itibarını dışarıya karşı savunacaklardır. Dolayısıyla örgütsel sinizm yaşayan işgörenler örgütlerine bağlanma gibi bir davranış sergilemeyeceklerdir. Çünkü işgören bulunduğu örgütün tüm uygulamalarının dürüstlükten uzak olduğuna inanmaktadır.

- $\quad$ Örgütsel Vatandaşlık: Örgütsel vatandaşlık kavramı zorlamaya dayalı olmayan, örgüt etkinliğini arttırmaya yönelik ve bireysel gönüllülüğe dayalı davranışlardır. İşgören çalıştığı örgüte karşı ne kadar olumsuz duygu beslerse örgüte yönelik gerçekleştirdiği gönüllü davranışlarda o kadar azalma meydana gelir. Bu durumda örgütsel sinizm ile örgütsel vatandaşlık davranışının ters orantılı olduğunu belirtebiliriz.

- Tükenmişlik: Maslach'a göre tükenmişlik, insanlarla işi gereği yoğun ilişkiler içerisinde bulunmak zorunda olan işgörenlerin yaşadığ duyarsızlaşma, tükenme ve düşük başarı hissi durumlarıdır. Tükenmişlik ile örgütsel sinizm arasında ortak olan kavramlar hayal kırıklığı, insanları hor görme ve küçümseme şeklindedir. Dolayısıyla örgütsel sinizm ile tükenmişlik arasında pozitif yönlü bir ilişki bulunmaktadır. Bu durum ikisinin de motivasyon düşüklüğü, yorgunluk, enerji kaybı gibi ortak sonuçlarından kaynaklanmaktadır.

- Güven: Sinizm duygusunu taşıyan işgörenlerde temelde güvensizlik hissi yatmaktadır. İşgörenler yöneticilerinin yönetim şekillerinde güvensizlik hissederlerse örgütsel sinizm ortaya çıkar.

- Yabancılaşma: Örgütsel sinizm beraberinde yabancılaşmayı meydana getirmektedir. Bu demektir ki işgören işini anlamsız bulmakta, çalıştığ1 örgüt içinde yalnız, güçsüz ve umutsuz hissetmektedir. Böylece örgütsel sinizm de ve işe yabancılaşma da artmaktadır.

- $\quad$ Örgütsel Adalet: İşgören çalıştığı örgütte adil davranılmadığını hissederse örgütsel adaletsizlik meydana gelir. Bunun sonucunda da güvensizlik, tatminsizlik, örgüte bağlılıkta azalma gibi olumsuz sonuçlar oluşmaktadır.

Örgütsel sinizmi gidermek için; 
Örgütsel sinizmin etkilerini azaltmak için bu kavramla ilişkili olan diğer kavramları baz alarak çözüm yolları arayışında olmak gereklidir. Bu çözüm yolları şu şekilde belirtilebilir (Mülayim, 2019: 54):

- $\quad$ Yönetim anlayışı hesap verici nitelikte olmalıdır.

- $\quad$ İşgörenlere kendilerini ifade etmeleri için imkân tanınmalıdır.

- $\quad$ Örgüt içerisinde adaletli bir ortam sağlanmalıdır.

tanınmalıdır.

Her işgörenin kabiliyetini sergileyebilmesi için imkân imkânı tanınmalıdır.

tutulmalıdır.

Örgüt içerisinde sinizme yönelmeyi engellemek adına rotasyon İşgörenler değişime açık olmaları konusunda eğitime tabi

- İşgörenlere ulaşabilecekleri hedefler verilmelidir (K1sa veya uzun vadeli).

E. Sanal Kaytarma ve Örgütsel Sinizm ile İlgili Yurtiçi ve Yurtdışı Çalışmalar

Yazında iki kavram arasındaki ilişkiyi ele alan çalışma bulunmamaktadır. $\mathrm{Bu}$ sebeple araştırmanın bu kısmında sanal kaytarma davranışının ve sinizm davranışının farklı değişkenlerle ilişkilerini değerlendirmek amacıyla literatürde yapılmış olan yurtiçi ve yurtdışı çalışmalardan örnekler verilmiştir. Bu çalışmalar şu şekildedir:

Keklik vd. (2015) tarafından yapılan çalışmada sanal kaytarmanın örgütsel öğrenmeye olan etkisi tespit edilmiştir. Bu amaçla Isparta'da bulunan bir kamu üniversitesinde çalışmakta olan 104 idari personel arasında bir anket çalışması gerçekleştirilmiştir. Yapılan regresyon ve korelasyon analizleri neticesinde sanal kaytarma davranışlarının örgütsel öğrenme kapasitesini pozitif yönde etkilediği tespit edilmiştir (Keklik vd. , 2015: 133-139).

Kâhya (2018) tarafından yapılan çalışmada sanal kaytarmanın çalışma performansına etkisini bir devlet üniversitesinde çalışmakta olan 212 akademisyen ile bir anket çalışması gerçekleştirilmiştir. Yapılan analizler neticesinde hem sanal kaytarma ile çalışma performansı arasında anlamlı ilişkilerin olduğu görülmüştür (Kâhya, 2018: 860-870).

Babadağ (2018) bir belediyede masa başında memur olarak çalışmakta olan 187 işgören arasında işe yabancılaşmanın sanal kaytarma üzerindeki etkisini tespit etmeyi amaçlamıştır. Bu amaçla belediye çalışanları arasında anket tekniğinden yararlanılarak veriler toplanmış ve SPSS, AMOS programları ile toplanan veriler analiz edilmiştir. Yapılan açıklayıcı faktör analizi, doğrulayıcı faktör analizi, korelasyon analizi ve regresyon analizi neticesine göre işe yabancılaşmanın sanal kaytarmayı pozitif yönde ve anlamlı olarak etkilediği tespit edilmiştir (Babadağ, 2018: 207-231).

Çavuşoğlu ve Palamutçuoğlu (2017) iş tatmininin sanal kaytarma üzerindeki etkisini tespit etmek amaciyla Celal Bayar Üniversitesi'nde görev yapmakta olan 375 akademik ve idari personel arasında bir anket çalışması gerçekleştirmiştir. Yapılan analizlerin neticesine göre iş tatmininin sanal 
kaytarmayı negatif yönde etkilediği belirlenmiştir (Çavuşoğlu ve Palamutçuoğlu, 2017: 430-444).

Yaşar ve Yurdugül (2013) yükseköğretimdeki öğrenciler arasında sanal kaytarma davranışları arasındaki ilişkiyi tespit etmeyi amaç edinmiştir. Bu amaçla 215 yükseköğretim öğrencisi arasında bir anket çalışması uygulamıştır. Yapılan analizler neticesinde sanal kaytarmanın öğrencilerin kaçış ve gelişim açısından davranışları ile anlamlı bir ilişkisi bulunmamaktadır. Fakat sanal kaytarmanın öğrencilerin bağımlılık davranışları ile anlamlı bir ilişkisi olduğu tespit edilmiştir (Yaşar ve Yurdugül, 2013: 600-604).

Kutanis vd. (2014) iş stresinin sanal kaytarma üzerindeki etkisini belirlemek amaciyla internete bağlı bilgisayar kullanan çalışanlar arasında bir anket çalışması düzenlemiştir. Analiz sonuçlarına göre iş stresinin alt boyutları olan iş yükü ve karar serbestisi ile sanal kaytarma davranışları arasında bir ilişki tespit edilememiştir. Ancak ciddi sanal kaytarma davranışı ile sosyal destek alt boyutu arasında pozitif yönde anlamlı bir ilişki olduğu görülmüştür (Kutanis vd. , 2014).

İyigün vd. (2014) sanal kaytarma davranışlarının psikolojik sözleşmeyle ilişskisini tespit etmek amacıyla yaptıkları çalışmada işlemsel psikolojik sözleşmeyle sanal kaytarma arasında pozitif yönlü ve anlamlı bir ilişki tespit edilmiştir (İyigün, 2014).

Aslan ve Boylu (2014) sinizm ile psikolojik sözleşme ihlali arasındaki ilişkiyi belirlemek amacıyla Ankara'da bulunan beş yıldızlı otellerde çalışmakta olan 390 personel arasında bir anket çalışması gerçekleştirilmiştir. Yapılan istatistiksel analizlerin neticesine göre sinizm ile psikolojik sözleşme ihlali arasında pozitif yönlü ve anlamlı bir ilişki olduğu tespit edilmiştir (Aslan ve Boylu, 2014: 33-45).

Yıldırım (2018) tükenmişliğin sanal kaytarma üzerindeki etkisinde iş doyumunun aracılık rolünü belirlemek amacıyla gerçekleştirdiği çalışmada 119 serbest muhasebeci ve mali müşavir arasında bir anket çalışması düzenlemiştir. Yapılan analizlere göre iş doyumunun önemli sanal kaytarmayı azaltıcı bir etkisinin olduğu, iş doyumunun duyarsızlaşma ve önemli sanal kaytarma arasındaki ilişkide aracılık ettiği ve tükenmişliğe ait tüm alt boyutların iş doyumunu olumsuz etkilediği tespit edilmiştir (Yıldırım, 2018: 302-313).

Aghaz ve Sheikh (2016) bilgi teknolojileri üzerine çalışan bir kurumdaki 298 kişi arasında bir anket çalışması düzenlemişlerdir. Yapılan analizler neticesinde sanal kaytarma ile mesleki tükenmişlik arasında pozitif yönlü bir ilişkinin bulunduğu tespit edilmiştir (Aghaz ve Sheikh, 2016: 51-60).

Blanchard ve Henle (2008) 201 lisansüstü öğrencisi arasında bir anket çalışması gerçekleştirmiştir. Araştırmanın sonuçlarına göre yöneticilerin normlarının önemsiz sanal kaytarma ile pozitif yönlü ilişkide olduğu, önemli sanal kaytarma ile ilişkili olmadığı tespit edilmiştir (Blanchard ve Henle, 2008: 10671084).

Sawitri (2012) 199 kişi üzerinde uyguladığı anket çalışmasını yerel yönetim örneklemi üzerinde gerçekleştirmiştir. Analizlerin sonucuna göre rol 
çatışması ve rol belirsizliğinin sanal kaytarma ile anlamlı ve pozitif yönde bir ilişkisinin olduğu sonucuna ulaşılmıştır (Sawitri, 2012: 320-324).

Shahzad ve Mahmood (2012) tarafından yapılan çalışmada Pakistan'daki özel bankalarda çalışmakta olan 332 işgören arasında bir anket çalışması düzenlenmiştir. Araştırmanın sonuçları örgütsel sinizm ile örgütteki sapkın davranışlar arasında anlamlı ve olumlu bir ilişkinin olduğunu göstermektedir (Shahzad ve Mahmood, 2012: 580-588).

Barnes (2010) sinizm ile örgütsel aidiyet arasındaki ilişkiyi 473 kişi üzerinde anket tekniği yardımıyla tespit etmiştir. Araştırmanın sonuçları işgörenlerin örgütsel bağl1lıkları ile örgütsel sinizm algıları arasında negatif yönlü bir ilişkinin olduğunu göstermektedir (Barnes, 2010).

Bedeian (2007) tarafından yapılan çalışmada örgütsel sinizm ile işten ayrılma niyeti arasındaki ilişki belirtilmiştir. Bu amaçla 379 akademisyen arasında bir anket çalışması düzenlenmiş olup, yapılan analizlerde sinizm ile örgütsel aidiyet arasında negatif yönlü bir ilişkinin olduğu görülmüştür (Bedeian, 2007: 9-32).

Çakıcı ve Doğan (2014)'ın örgütsel sinizmin iş performansına etkisini belirlemeye yönelik yaptığı çalışma 184 akademik ve idari personel arasında anket tekniği yardımıyla gerçekleştirilmiştir. Yapılan analizler neticesinde iş performansı üzerinde örgütsel sinizmin etkisinin olmadığı tespit edilmiştir (Çakıcı ve Doğan, 2014: 79-89).

Akdemir vd. (2016) tarafından yapılan çalışmada örgütsel sinizm ile iş performansı arasındaki ilişkiyi tespit etmek amacıyla Munzur ve Kafkas Üniversiteleri'nde görev yapmakta olan akademik, idari ve geçici hizmetli 384 personel arasında bir anket çalışması düzenlenmiştir. Yapılan analizlerin neticesine göre bilişsel, duygusal ve davranışsal boyutta örgütsel sinizm ile iş performans1 arasında anlamlı ilişkilerin olduğu tespit edilmiştir (Akdemir vd. , 2016: 115-128).

Bacaksız vd. (2018)'nin sağlık çalışanları üzerinde performans ve örgütsel sinizm ilişkisini tespit etmeye yönelik yaptıkları çalışmada, kamu ve özel sektörlerde çalışmakta olan 240 hemşireye anketler uygulanmıştır. Yapılan analizlerin sonuçlarına göre sinizmin çalışma performansını negatif yönde etkilediği tespit edilmiştir (Bacaksız vd. , 2018: 52-58).

Çopur ve Başkan (2019) 472 öğretim elemanı arasında örgütsel demokrasi ile örgütsel sinizm arasındaki ilişkiyi tespit etmek amacıyla bir anket çalışması düzenlemiştir. Yapılan analizlerin sonucuna göre ankete katılan öğretim elemanlarının örgütsel demokrasi düzeyleri ile bilişsel ve duyuşsal sinizm tutumları arasında yüksek düzeyde ve negatif yönlü, davranışsal sinizm tutumları arasında ise orta düzeyde negatif yönlü bir ilişki olduğu görülmüştür (Çopur ve Başkan, 2019: 1-12).

Kökalan ve Anaş (2016) 284 vakıf üniversitesi çalışanı arasında gerçekleştirdiği bu çalışmada örgütsel sinizmin işe yabancılaşma üzerindeki etkisini tespit etmeyi amaçlamıştır. Analiz sonuçları örgütsel sinizm ile işe yabancılaşma arasında pozitif yönde ve anlamlı bir ilişkinin olduğunu, örgütsel sinizmin işe yabancılaşma üzerinde pozitif yönde anlamlı etkilerinin bulunduğunu göstermektedir (Kökalan ve Anaş, 2016: 97-109). 
Gökyer ve Türkoğlu (2018) 2805 öğretmen arasında gerçekleştirdiği anket çalışmasında örgütsel destek algıları ile sinizm tutumları arasındaki ilişkiyi belirlemiştir. Yapılan analizlere göre bilişsel ve duyuşsal sinizm ile örgütsel destek algıları arasında negatif ilişki, davranışsal sinizm ile örgütsel destek algıları zayıf ve negatif bir ilişki olduğu tespit edilmiştir (Gökyer ve Türkoğlu, 2018: 317-340).

Yıldırım ve Karabey (2017) etik iklimin sanal kaytarma üzerindeki etkisinde örgütsel sinizmin aracılık rolünü belirlemek amacıyla gerçekleştirdiği çalışmada bankacılık sektöründe çalışmakta olan 217 işgören üzerinde anket tekniğini uygulamıştır. Çalışanların örgütsel etik iklim algılarının sanal kaytarma davranışları üzerinde anlamlı etkisinin bulunduğu tespit edilmiştir (Yıldırım ve Karabey, 2017: 557-594).

Gün ve Başkan (2017)'1n örgütsel sinizm ve tükenmişlik düzeyleri arasındaki ilişkiyi belirlemeye yönelik anket çalışmasına Ankara'da bulunan dört devlet üniversitesinde görev yapmakta olan 392 öğretim elemanı katılmıştır. Yapılan analizler neticesinde örgütsel sinizm ile tükenmişliğin alt boyutlarından duyarsızlaşma ve duygusal tükenme arasında anlamlı bir ilişki olduğu tespit edilmiştir (Gün ve Başkan, 2017: 361-379).

Erkutlu ve Özdemir (2018) tarafından yapılan çalışmada otantik liderlik ile sanal kaytarma arasındaki ilişkide örgütsel sinizmin aracılık rolü tespit edilmiştir. $\mathrm{Bu}$ amaçla Ahi Evran Üniversitesi’nde görev yapmakta olan 208 idari personel arasında bir anket çalışması düzenlenmiştir. Yapılan analizlerin neticesinde otantik liderlik ile sanal kaytarma arasında negatif yönlü bir ilişki olduğu, bu ilişkide örgütsel sinizmin aracılık rolünün bulunmadığı tespit edilmiştir (Erkutlu ve Özdemir, 2018: 119-125).

Alan ve Fidanboy (2013) çalışmasında sinizm, tükenmişlik ve kişilik arasındaki ilişkileri tespit etmeyi amaçlamıştır. Araştırmanın örneklemini 45 bilişim sektörü çalışanı oluşturmaktadır. Yapılan analiz sonuçlarına göre işgörenlerin örgütsel sinizm ile tükenmişlikleri arasında anlamlı ve pozitif yönlü bir ilişki olduğu görülmüştür (Alan ve Fidanboy, 2013: 165-176).

Yazıcıoğlu ve Gençer (2017)'in örgütsel adalet algısının sinizm üzerindeki etkisini tespit etmeye yönelik yapmış oldukları çalışmada Türkiye'deki devlet üniversitelerinde görev yapmakta olan 400 öğretim görevlisi arasında bir anket çalışması düzenlenmiştir. Yapılan analizlerin neticesine göre örgütsel adalet algısı ile örgütsel sinizm arasında negatif yönlü ve anlamlı bir ilişkinin olduğu tespit edilmiştir (Yazıcıoğlu ve Gençer, 2017: 106-119).

Geçmişte yapılmış olan çalışmalarda sinizmin genel olarak örgütsel bağ lılık ile ilişkilendirildiği tespit edilmiştir. Bu ilişkiye örnek olarak aşağıdaki çalışmalar verilebilir:

Yavuz ve Bedük (2016)'ün örgütsel sinizm ve örgütsel bağl1l1k arasındaki ilişkiyi tespit etmeye yönelik yaptıkları çalışma bir kamu bankasının Konya ilindeki şubelerinde çalışmakta olan 85 personele uygulanmıştır. Yapılan analizler neticesinde örgütsel sinizm ile örgütsel bağlılık arasında negatif yönlü ve anlamlı bir ilişki olduğu tespit edilmiştir (Yavuz ve Bedük, 2016: 301-313). 
Nafei ve Kaifi (2013) tarafından yapılan çalışma örgütsel sinizmin örgütsel bağlılık üzerindeki etkisini tespit etmek amacıyla yapılmıştır. Bu sebeple Mısır'da görev yapan 297 hastane çalışanı arasında bir anket çalışması düzenlenmiştir. Analizlerin neticesine göre örgütsel sinizm ile örgütsel bağlılık arasında anlamlı bir ilişki bulunduğu belirlenmiştir (Nafei ve Kaifi, 2013: 131-146).

Erdirençelebi ve Yazgan (2017) mobbing, örgütsel sinizm, örgütsel bağl1lık ve bunların algılanan işgören performansı üzerindeki etkisini tespit etmek amacıyla orta ölçekli 417 işletme arasında bir anket çalışması gerçekleştirmiştir. Yapılan analizlerin neticesine göre işgörenlere yapılan mobbing davranışının sinizm üzerinde pozitif yönlü, örgütsel bağll11k ve performans üzerinde ise negatif yönlü etkisinin olduğu tespit edilmiştir (Erdirençelebi ve Yazgan, 2017: 267-284).

Bernerth vd. (2007) örgütsel sinizm ile örgütsel bağl1lık arasındaki ilişkiyi tespit etmek amacıyla 117 gönüllü katılımcı arasında bir anket çalışması düzenlemiştir. Araştırmanın sonuçlarına göre örgütsel sinizmin örgütsel bağlılık için yordayıcı bir güç olduğu tespit edilmiştir ( Bernerth vd. , 2007: 303-326).

\section{ARAŞTIRMANIN YÖNTEMI VE HIPOTEZLERI}

Çalışmanın temel varsayımı sanal kaytarma davranışının örgütsel sinizm davranışı ile ilişkili olması ve sinizm davranışında gerçekleşen artışın sanal kaytarma davranışını da arttırması üzerinedir. Araştırma örgütsel sinizm davranışının sanal kaytarma davranışı üzerindeki etkisinde örgüt çalışanlarının yaş düzeylerini düzenleyici rolünü değerlendirmek açısından keşfedici niteliktedir. Sanal kaytarma davranışı ile sinizm arasındaki ilişkiyi belirlemek amacıyla Brandes (1997) tarafından geliştirilen, Tokgöz ve Yılmaz (2008) tarafindan Türkçe'ye uyarlanan 'Örgütsel Sinizm Ölçeği', kullanılmıştır. Ayrıca sanal kaytarma ölçeği olarak Blanchard ve Henle (2008) tarafından geliştirilen ve Altunışık vd. (2002) tarafında Türkçe'ye çevrilen ölçek kullanılmıştır. Sinizm ve sanal kaytarma değişkenleri için (1=Kesinlikle Katılmıyorum, 5=Kesinlikle Katılıyorum) 5'li Likert tipi ölçek kullanılmıştır. Araştırmanın evrenini Balıkesir' in Bandırma ilçesinde bulunan bir kamu iktisadi teşebbüsünde çalışmakta olan 350 personel oluşturmaktadır. Örneklem olarak 200 personele anket çalışması gerçekleştirilmiştir. Dağıtılan 200 anketten 31 tanesi üstünkörü doldurulduğu için değerlendirilmeye tabi tutulmamıştır. Bu sebeple analizler kalan 169 anket ile yapılmıştır.

Araştırmanın hipotezleri sosyal değişim kuramı 1şığında geliştirilmiştir.

Araştırmanın temel hipotezleri ve alt hipotezi aşağıdaki gibidir:

$\mathbf{H}_{1}$ : Sinizm ile sanal kaytarma davranışı arasında pozitif yönlü ve anlamlı bir ilişki vardır.

$\mathbf{H}_{2}$ : Sinizmin sanal kaytarma davranışı üzerinde anlamlı bir etkisi vardır.

$\mathbf{H}_{2 \mathrm{a}}$ : Sinizmin sanal kaytarma davranış1 üzerindeki etkisinde çalışan yaşlarının hızlandırıcı rolü vardır.

\section{ARAŞTIRMANIN BULGULARI}

Araştırma verilerinin analizinde farklı istatistik yöntemleri kullanılmış ve araştırma sonucunda elde edilen bulgular aşağıda özetlenmiştir. 
Araştırma tek bir işletmede yapıldığ 1 için aşağıdaki bulgulara ilişkin analiz ve yorumlar genellenebilir nitelikte değildir. Sonuçlar araştırma örneklemi ile kisitlidir.

Tablo 1. Araştırmaya Katılan Kişilere İlişkin Demografik Verilerin Dağılımı

\begin{tabular}{|c|c|c|c|}
\hline Değişkenler & Alt Gruplar & Frekans & Yüzde (\%) \\
\hline \multirow[t]{2}{*}{ Cinsiyet } & Kadın & 60 & 35,5 \\
\hline & Erkek & 109 & 64,5 \\
\hline \multirow[t]{5}{*}{ Yaş } & 18-24 yaş arası & 10 & 5,9 \\
\hline & 25-31 yaș arası & 39 & 23,1 \\
\hline & 32-38 yaş arası & 56 & 33,1 \\
\hline & 39-45 yaş arası & 37 & 21,9 \\
\hline & 46 yaş ve üstü & 27 & 16 \\
\hline \multirow[t]{5}{*}{ Eğitim Durumu } & Ortaögretim mezunu & 4 & 2,4 \\
\hline & Lise mezunu & 47 & 27,8 \\
\hline & Ön lisans mezunu & 41 & 24,3 \\
\hline & Lisans mezunu & 72 & 42,6 \\
\hline & $\begin{array}{l}\text { Yüksek lisans/doktora } \\
\text { mezunu }\end{array}$ & 5 & 3 \\
\hline \multirow[t]{5}{*}{ Kurumda Çalışma Süresi } & 1 Yıldan az & 5 & 3 \\
\hline & 1-6 yıl arası & 41 & 24,3 \\
\hline & 6-10 yıl arası & 48 & 28,4 \\
\hline & $11-15$ yıl arası & 32 & 18,9 \\
\hline & 15 ve üstü yıl & 43 & 25,4 \\
\hline
\end{tabular}

Tablo 1'de katılımcıların demografik değişkenleri, frekans değerleri ve yüzdeleri ayrıntılı olarak verilmiştir. Ankete katılan kadın sayısının $60(\% 35,5)$ ve erkek sayısının $109(\% 64,5)$ olduğu görülmektedir. Bu durumda katılımcıların çoğunluğunun erkek, 32-38 yaş arası $(\% 33,1)$, lisans mezunu $(\% 42,6)$ ve kurumda çalışma süresinin 6-10 yıl arası $(\% 28,4)$ olduğu tespit edilmiştir.

Sinizm ve sanal kaytarma değişkenlerine ait güvenilirlik değerleri tablo 2 de ifade edilmiştir.

Tablo 2. Güvenilirlik Analizine İlişkin Bulgular

\begin{tabular}{|c|c|c|}
\hline Ölçek & Örneklem Sayısı & Cronbach's Alpha \\
\hline Sanal Kaytarma & 169 & 0,90 \\
\hline Sinizm & 169 & 0,85 \\
\hline
\end{tabular}

Tablo 2'ye göre araştırmada kullanılan sanal kaytarma ölçeğinin güvenilirlik katsayısı (Cronbach's Alpha değeri) 0,90 ve sinizm ölçeğinin güvenilirlik katsayısı (Cronbach's Alpha değeri) 0,85 olarak tespit edilmiştir. Alpha katsayısı 0,70 üzerine yaklaştıkça ölçeğin güvenilir olduğu kabul edilir. Bu sebeple bulunan değerlerin güvenilirlik analizi sonuçları (Cronbach's Alpha değerleri) yüksek ve güvenilirdir.

Tablo 3. KMO ve Bartlett's Testi Tablosu

\begin{tabular}{|c|c|c|}
\hline \multicolumn{2}{|c|}{ Kaiser - Meyer -Olkin } &, 847 \\
\hline & Ki-Kare & 4265,602 \\
\hline Bartlett's Küresellik Testi & df &, 595 \\
\hline & Sig. &, 000 \\
\hline
\end{tabular}

Tablo 3'te ölçekler geçerlilik için keşfedici faktör analizine tabi tutulmuş olup, Kaiser Meyer Olkin (KMO) örneklem yeterliliği sonucu 0,847 olarak tespit edilmiştir. Bununla birlikte Bartlett's küresellik testinin sonucu da $p=0,000$ ve anlamlıdır $(\mathrm{p}<0,001)$. Bu test sonucu, faktör analizi için örneklem büyüklügünün 
yeterli sayıda olduğunu göstermektedir. Ayrıca ölçekler faktör yükleri açısından da kabul edilebilir düzeydedir.

\section{A. Araştırmanın Hipotezlerinin Test Edilmesi}

Tablo 4. Sanal Kaytarma ve Sinizm Arasındaki İlişki İçin Korelasyon Analizi Tablosu

\begin{tabular}{|c|c|c|c|}
\hline & & Sanal Kaytarma & Sinizm \\
\hline \multirow{3}{*}{ Sanal Kaytarma } & $\begin{array}{c}\text { Pearson } \\
\text { Correlation }\end{array}$ & 1 & \\
\cline { 2 - 4 } & Sig. & 0,000 & 1 \\
\hline \multirow{2}{*}{ Sinizm } & $\begin{array}{c}\text { Pearson } \\
\text { Correlation }\end{array}$ &, $337^{* *}$ &, 000 \\
\cline { 2 - 4 } & Sig. &, 000 & \multirow{2}{*}{} \\
\hline
\end{tabular}

Tablo 4'te değişkenler arasındaki ilişkiyi tespit etmek amacıyla yapılan korelasyon analizi sonuçları verilmiştir. Yapılan korelasyon analizi sonuçlarına göre sanal kaytarma davranışı ile sinizm davranışı arasında pozitif yönlü ve anlamlı bir ilişki olduğu ( $(169)$ : 0,337, p<0.05) tespit edilmiştir. Bu durumda sanal kaytarma davranışı ile sinizm davranışının birlikte artmakta veya birlikte azalmakta olduğu belirtilebilir. Bu sonuca göre (H: Sanal kaytarma davranışı ile sinizm arasında pozitif yönlü ve anlamlı bir ilişki vardır) hipotezi kabul edilmiştir.

Tablo 5. Bağımsız Değişkenin Bağımlı Değişken Üzerindeki Etkisi

\begin{tabular}{|l|l|l|l|l|l|}
\hline Model & B & Std. Hata & $\boldsymbol{\beta}$ & $\mathbf{T}$ & Sig. \\
\hline Sabit & & & & & \\
\hline Örgütsel Sinizm & 1,210 &, 186 & & 6,51 &, 000 \\
\hline
\end{tabular}

Bağımlı Değişken: Sanal Kaytarma

Bağımsız Değişken: Örgütsel Sinizm

Tablo 5'te sinizmin sanal kaytarma davranışlarını ne kadar belirlediğini incelemek üzere yapılan basit doğrusal regresyon analizinin sonuçları verilmiştir. Basit doğrusal regresyon analizinin sonuçları istatistiksel olarak anlamlıdır. $(\mathrm{p}<0,001)$ Bağımsız değişken olan sinizmde gerçekleşen bir standart sapmalık değişme, bağımlı değişken olan sanal kaytarma davranışında 0,337'lik standart sapma oranında değişmeye neden olmaktadır. Bu durumda ( $\boldsymbol{H}_{2}$ : Sinizmin sanal kaytarma davranışı üzerinde anlamlı bir etkisi vardır) hipotezi kabul olmuştur.

B. Düzenleyici Değişken ile Regresyon Analizi

Şekil 1. Temel Düzenleyicilik Modeli

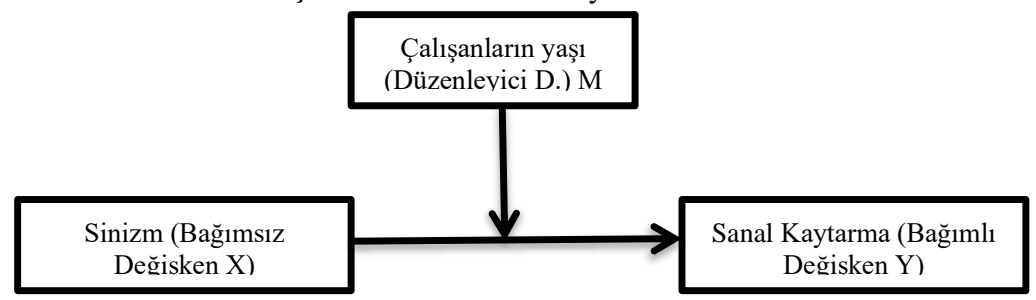

Şekil 1 düzenleyici değişkenin (yaş) yer aldığı modeli göstermektedir. Bağımsız değişken (X) ile bağımlı değişken (Y) arasındaki ilişkide düzenleyici değişkenin (M-yaş) etkisi belirtilmektedir. 
Edip Örücü \& Itır Hasırcı / Organizasyonlarda Sinizm ile Sanal Kaytarma Davranışı İlişkisinde Çalışan Yaşının Düzenleyici Etkisi

Tablo 6. Tanımlayıcı İstatistikler

\begin{tabular}{|c|c|c|c|}
\hline & Ort. & Std. Sapma & N \\
\hline Sanal Kaytarma & 2,0397 &, 652 & 169 \\
\hline Zscore: Sinizm & 2,2258 &, 589 & 169 \\
\hline Zscore: Yaș & 3,1893 & 1,138 & 169 \\
\hline XM &,- 0087 & 1,014 & 169 \\
\hline
\end{tabular}

Değişkenlere ait ortalama, standart sapma değerleri tablo 6'da belirtilmiştir.

Tablo 7. Değişkenler Arası İlişkiler

\begin{tabular}{|l|l|l|l|l|l|}
\hline & & $\begin{array}{l}\text { Sanal } \\
\text { Kaytarma }\end{array}$ & Zscore(Sinizm) & $\begin{array}{l}\text { Zscore(Sanal } \\
\text { Kaytarma) }\end{array}$ & XM \\
\hline Pearson & Sanal Kaytarma & 1,000 & & & \\
& Zscore(Sinizm) &, 337 & 1,000 & 1,000 & \\
& Zscore(Yaş) &, 129 &,- 009 &,- 002 & 1,000 \\
\hline XM &, 123 &,- 091 &, 047 &, 055 \\
& Sanal Kaytarma &. &, 000 &, 455 &, 120 \\
& Zscore(Sinizm) &, 000 &. &. &, 489 \\
& Zscore(Yaş) &, 047 &, 455 &, 489 &. \\
\hline NM &, 055 &, 120 & 169 & 169 \\
& XMation & & 169 & 169 & 169 \\
& Sanal Kaytarma & 169 & 169 & 169 & 169 \\
& Zscore(Sinizm) & 169 & 169 & 169 & 169 \\
\hline
\end{tabular}

Tablo 7 değişkenler arası ilişkileri gösteren korelasyon katsayılarını belirtmektedir. Tabloya göre bağımlı değişken sanal kaytarma ile bağımsız değişken sinizm arasında anlamlı ilişkilerin olduğu görülmektedir.

Tablo 8. Hiyerarşik Regresyon Modelinin Anlamlılık Sonuçları (ANOVA)

\begin{tabular}{|l|c|c|c|c|c|}
\hline \multicolumn{1}{|c|}{ Model } & $\begin{array}{c}\text { Sum of } \\
\text { Squares }\end{array}$ & df & $\begin{array}{c}\text { Mean } \\
\text { Square }\end{array}$ & F & Sig. \\
\hline 1 Regression & 9,381 & 2 & 4,690 & 12,520 &, $000^{\mathrm{b}}$ \\
\hline 1 Residual & 62,188 & 166 &, 375 & & \\
\hline Total & 71,569 & 168 & & &, $000^{\mathrm{c}}$ \\
\hline 1 Regression & 11,099 & 3 & 3,700 & 10,095 & \\
\hline 1 Residual & 60,470 & 165 &, 366 & & \\
\hline Total & 71,569 & 168 & & & \\
\hline
\end{tabular}

Bağımlı Değişken: Sanal Kaytarma

Tablo 8 düzenleyici değişken ile regresyon analizinin ikinci aşaması olan hiyerarşik regresyon analizinde yer alan modellerin anlamlılı sonucunu göstermektedir. Tabloda yer alan anlamlılık değeri (Sig.) 0,05 değerinden küçük olduğu için $(p<0,001)$ her iki regresyon modeli de istatistiksel olarak anlamlıdır.

Tablo 9. Hiyerarşik Regresyon Modeline Ait Katsayılar

\begin{tabular}{|c|c|c|c|c|c|c|c|}
\hline \multirow[t]{2}{*}{ Model } & \multicolumn{2}{|c|}{$\begin{array}{l}\text { Standartlaştırılmamış } \\
\text { Katsayılar }\end{array}$} & \multirow{2}{*}{$\begin{array}{l}\text { Standardize } \\
\text { Katsayılar } \\
\text { Beta }\end{array}$} & \multirow[t]{2}{*}{$\mathbf{t}$} & \multirow[t]{2}{*}{ Sig. } & & \\
\hline & $\beta$ & Std. Hata & & & & Tolerans & VIF \\
\hline $\begin{array}{l}1 \quad \text { (Constant) } \\
\text { Zscore(Sinizm) } \\
\text { Zscore(Yaș) }\end{array}$ & $\begin{array}{l}2,040 \\
, 221 \\
, 086\end{array}$ & $\begin{array}{l}, 047 \\
, 047 \\
, 047\end{array}$ & $\begin{array}{l}, 338 \\
, 132\end{array}$ & $\begin{array}{l}43,322 \\
4,676 \\
1,823\end{array}$ & $\begin{array}{l}, 000 \\
, 000 \\
, 070\end{array}$ & $\begin{array}{l}1,000 \\
1,000\end{array}$ & $\begin{array}{l}1,000 \\
1,000\end{array}$ \\
\hline $\begin{array}{l}2 \quad \text { (Constant) } \\
\text { Zscore(Sinizm) } \\
\text { Zscore(Yaş) } \\
\text { XM }\end{array}$ & $\begin{array}{l}2,041 \\
, 230 \\
, 086 \\
, 100\end{array}$ & $\begin{array}{l}, 047 \\
, 047 \\
, 047 \\
, 046\end{array}$ & $\begin{array}{l}, 352 \\
, 132 \\
, 156\end{array}$ & $\begin{array}{l}43,818 \\
4,905 \\
1,850 \\
2,165\end{array}$ & $\begin{array}{l}, 000 \\
, 000 \\
, 066 \\
, 032\end{array}$ & $\begin{array}{l}, 992 \\
1,000 \\
, 992\end{array}$ & $\begin{array}{l}1,008 \\
1,000 \\
1,008\end{array}$ \\
\hline
\end{tabular}

Bağımlı Değişken: Sanal Kaytarma 
Tablo 9'da hiyerarşik regresyon analizine göre katsayılar verilmiştir. Düzenleyici model testi kapsamında standartlaştırılmamış katsayılar sütununa bakılmalıdır. Birinci grupta modele girilen değişkenlerden sinizmin $(B=0,221$, $\mathrm{p}<0,001)$ ve kurumda çalışanların yaşlarının ortalamasının $(B=0,086, p<0,001)$ sanal kaytarma davranışı üzerinde anlamlı bir etkisi bulunmaktadır. İkinci grupta modele girilen etkileşimsel terimle birlikte sonuçlara bakılırsa; birinci gruptaki değişkenlerden sinizmin $(B=0,221, p<0,001)$ ve kurumda çalışanların yaşlarının ortalamasının $(B=0,086, p<0,001)$; ikinci gruptaki etkileşimsel terimin ise $(B=0.10$, $\mathrm{p}<0,001)$ sanal kaytarma davranışı üzerinde anlamlı etkisinin olduğu görülmektedir. Bu durumda ( $\boldsymbol{H}_{2 a}$ : Sinizmin sanal kaytarma davranışı üzerindeki etkisinde kurumda çalışanların yaşlarının düzenleyici bir etkisi vardır) hipotezi kabul olmuștur.

Moderatör değişkene (XM) bakıldığında $(0,032) 0,05$ değerinden küçük olduğu için moderatör değişkenin bir etkisinin olduğu belirtilebilir. Sonuç olarak hiyerarşik regresyon modelinin her iki adımı da istatiksel bakımdan anlamlı olarak görülmektedir. Birinci model için Tolerance değerlerini karşılaştırmamız gereken kritik değer $1-\mathrm{R}^{2}=1-0,131=0,869$ 'dur. Birinci modelde yer alan bağımsız değişkenlerin Tolerance değerleri bu kritik değerden büyüktür. İkinci model için bakıldığında 1-0,155 = 0,845'dir. İkinci modelde yer alan bağımsız değişkenlerin Tolerance değerleri bu kritik değerden büyüktür. Bu durumda birinci ve ikinci modelde bulunan değişkenler için çoklu eş doğrusallık problemi olmadığ 1 söylenebilir.

Şekil 2. Sinizmin Sanal Kaytarma Üzerindeki Etkisinde Çalıșanların Yaşlarının Rolü

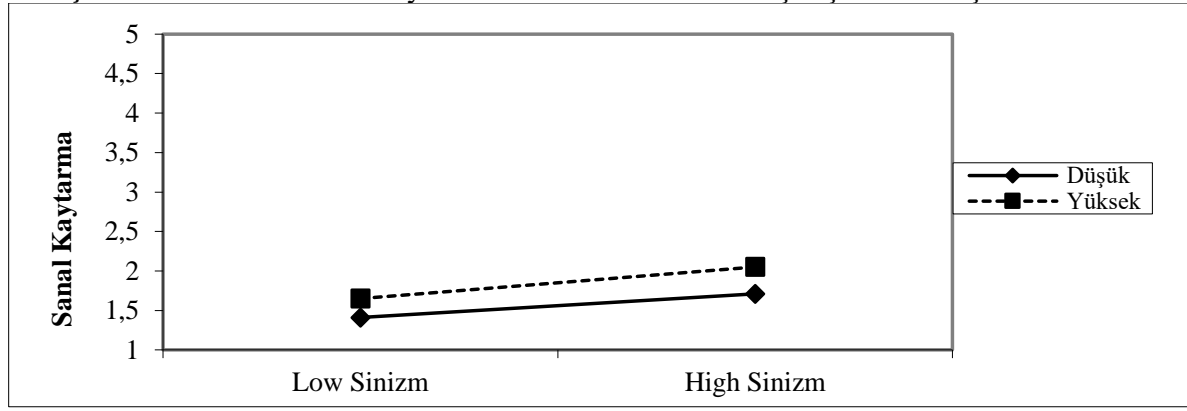

Şekil 2'deki düzenleyici etki grafiği örgütte çalışanların yaşlarının sanal kaytarma ve sinizm arasındaki ilişkide düzenleyici rolü olduğunu göstermektedir. Sinizm ile çalışanların yaşlarının en yüksek olduğu noktalar aynı zamanda sanal kaytarma davranışlarının da en yüksek olduğu noktalardır. Başka bir deyişle sinik davranış sergileyen çalışanların yaş seviyeleri yükseldikçe sanal kaytarma davranışları da anlamlı şekilde daha yüksek gerçekleşmektedir.

Tablo 10. Hipotez Red- Kabul Tablosu

\begin{tabular}{|c|c|}
\hline $\begin{array}{c}\mathbf{H}_{1} \text { : Sanal kaytarma davranışı ile sinizm davranışı } \\
\text { arasında pozitif yönlü ve anlamlı bir ilişski vardır. }\end{array}$ & KABUL \\
\hline $\begin{array}{c}\mathbf{H}_{2} \text { : Sinizmin sanal kaytarma davranışı üzerinde anlamlı } \\
\text { bir etkisi vardır. }\end{array}$ & $\boldsymbol{K A B U \boldsymbol { L }}$ \\
\hline $\begin{array}{c}\mathbf{H}_{2} \text { : Sinizmin sanal kaytarma davranışı üzerindeki } \\
\text { etkisinde kurumda çalışanların yaşlarının düzenleyici } \\
\text { bir etkisi vardır. }\end{array}$ & $\boldsymbol{K A B U L}$ \\
\hline
\end{tabular}




\section{SONUÇ VE DEĞERLENDİRME}

Örgütler ortak bir gayeyi gerçekleştirmek için birden fazla kişinin bir araya gelerek oluşturduğu ve iletişim halinde olduğu bir topluluktur. Örgüt yönetiminde bulunanlar çalışanlarının performanslarını negatif yönde etkileyecek her türlü etkeni ortadan kaldırmak için uğraşsalar dahi birçok insan kaynaklı problem ortaya çıkabilmektedir. Bu problemlere örnek olarak sanal kaytarma ve sinizm verilebilir.

Gelişen dünyada teknoloji ve bilişim üzerine yapılan yenilikler bireyleri etkilediği kadar örgütleri de etkilemektedir. Ancak bu sanal dünya iyi yönetilmezse olumsuz olaylara sebebiyet verebilecektir (Greengard, 2000: 22-24). İnternet kullanımının kolay hale gelmesi ve cep telefonları ile internete ulaşmanın mümkün olması dolayısıyla gerçekleşen iş dışı internet kullanımları sanal kaytarma davranışına imkân tanımaktadır. Sanal kaytarma davranışları bu yönüyle örgütlerde ciddi verimlilik kayıplarına neden olmaktadır. Bu kavram diğer yüzüyle de çalışanların iş hayatına katkı da sağlayabilmektedir (Çavuşoğlu ve Palamutçuoğlu, 2017: 430-444).

Örgütsel sinizm, tehdit unsuru olarak görülebilen, kişinin çalıştığ 1 örgüte yönelik olumsuz düşünceleridir. Sinizmin oluşmasına neden olan pek çok kavram bulunmaktadır. Bunlar mobbing, liderlikte etkin olamamak, güç dağılımlarında adaletsizlik, yönetimin kötü olması, çalışma saatlerinin uzun olması, performans düşüşleri, terfi sürelerinin gecikmesi, stres vb. şeklinde siralanabilmektedir (Reichers vd., 1997: 48-59). Örgütsel sinizmin ortaya çıkmasındaki ana neden örgütün dürüstlükten uzaklaşmaya başlaması ve bu durumunda işgören üzerinde olumsuz etkiler yaratması şeklinde açıklanabilir. Böylece sinik bireyler sinizm seviyeler arttıkça çalıştıkları örgüte karşı nefret duymaya başlarlar.

Araştırmanın evreni Balıkesir'in Bandırma ilçesinde bulunan bir kamu iktisadi teşebbüsünde çalışmakta 350 iş görendir ancak 200 işgören ile bir anket çalışması gerçekleştirilmiş olup 31 anketin gelişigüzel doldurulması sebebiyle 169 işgören ile anket çalışması gerçekleştirilmiştir. Ankete katılanların çoğunluğu 3238 yaş arası $(\% 33,1)$ iş görenden oluşmaktadır. Katılımcıların cinsiyetinin çoğunluğunu 109 kişi ile $(\% 64,5)$ erkekler oluşturmaktadır. Araştırmada ölçeklerin güvenilirlik analizleri yapılmıştır ve Cronbach's Alpha değerleri 0,90 ile 0,85 olarak bulunmuştur. Yapılan korelasyon analizi neticesinde sanal kaytarma davranışı ile sinizm davranışı arasında anlamlı bir ilişki olduğu tespit edilmiştir. Elde edilen sonuca göre ( $H_{1}$ : Sanal kaytarma davranışı ile sinizm davranışı arasında pozitif yönlü ve anlamlı bir ilişki vardır) hipotezi kabul olmuştur. Örgütsel sinizm davranışlarının sanal kaytarma davranışını arttırdığını göz önüne aldığımızda; çalışanların çalıştıkları örgüte karşı olumsuz tutumlar geliştirmesi olarak da bilinen sinik davranışları azaltmak için gerekli çalışmaların yapılması son derece önem arz etmektedir. Basit doğrusal regresyon analizi neticesine göre ise bağımsız değişken sinizmin bağımlı değişken sanal kaytarma üzerinde anlamlı bir etkisinin olduğu tespit edilmiştir. Yapılan analiz sonucuna göre $\left(\boldsymbol{H}_{2}\right.$ : Sinizmin sanal kaytarma davranışı üzerinde anlamlı bir etkisi vardır) hipotezi kabul olmuştur. 
$\mathrm{Bu}$ durumda yöneticilere sanal kaytarma davranışlarını azaltmaları için çalışanlara kendilerini ifade etmeleri hususunda imkân tanımaları, örgüt içerisinde adaleti sağlamaları, çalışanları rotasyona yönlendirebilmeleri vb. tavsiyeler verilebilir. İşgörenlerin yaş ortalamalarının bağımlı ve bağımsız değişken arasındaki ilişkide hızlandırıcı etkisini belirlemek amacıyla hiyerarşik regresyon analizi yapılmıştır. Yapılan analizler neticesinde bağımlı değişken sanal kaytarma ile bağımsız değişken sinizm ve kurumda çalışan yaşları arasında istatistiksel bakımdan anlamlı ilişkiler olduğu, örgüt çalışanlarının yaşlarının sanal kaytarma davranışı üzerinde anlamlı etkisinin bulunduğu sonucuna ulaşılmıştır. Sonuç olarak $\left(\mathrm{H}_{2 a}\right.$ : Sinizmin sanal kaytarma davranışı üzerindeki etkisinde kurumda çalışanların yaşlarının düzenleyici bir etkisi vardır)hipotezi kabul olmuştur. Çalıştığı örgütte yeni olan işgörenler işsiz kalma korkusuyla ve işinde kendini ön plana çıkarma duygusuyla hareket edecekleri için sanal kaytarma davranışına işinde tecrübeli çalışanlar kadar başvurmayacaklardır. Ancak daha tecrübeli çalışanlar uzun süredir aynı kurumda çalışmanın ve görevini daha iyi yapabileceğinin verdiği güvenle, kendini örgüt içi yeniliklerden de soyutlayarak sanal kaytarma davranışına daha çok başvuracaklardır. Bu durumda yöneticilere çalışanların sinik davranışlarının altında yatan nedenleri belirleyip, iyileştirmeye yönelik çaba harcamaları hususunda tavsiyeler verilebilir. Sinizm davranışlarının azalması hem sanal kaytarmayı azaltacak hem de zamanın boşa geçmesini engelleyecektir. Örgütler için sanal kaytarma ve sinizm davranışlarında azalma olursa verimlilik ve performansın yükselebileceği belirtilebilir.

\section{Araştırma ve Yayın Etiği Beyanı}

Makalenin tüm süreçlerinde Yönetim ve Ekonomi Dergisi'nin araştırma ve yayın etiği ilkelerine uygun olarak hareket edilmiştir.

Yazarların Makaleye Katkı Oranları

Yazarlar çalışmaya eşit oranda katkı sağlamıştır

\section{Çıkar Beyanı}

Yazarın herhangi bir kişi ya da kuruluş ile çıkar çatışması yoktur.

\section{KAYNAKÇA}

Abraham, R. (2000). 'Organizational Cynicism: Bases and Consequences. Genetic', Social and General Psychology Monographs, 126(3), 269-292.

Ada, Ş. ve Yarım, M. A. (2017). ' ’Ilkokullarda Görev Yapan Öğretmenlerin Örgütsel Sinizm Algıları: Erzurum İli Örneği”’. I Ĭdır Üniversitesi Sosyal Biimlerl Dergisi , (13), 66-98.

Aghaz, A. and Sheikh, A. (2016). 'Cyberloafing and Job Burnout: An Investigation in the Knowledge-intensive Sector'. Computers in Human Behavior, (62), 51-60.

Akdemir, B., Kırmızıgül, B. ve Zengin , Y. (2016). 'Örgütsel Sinizm ile İş Performansı Arasındaki İlişki ve Bir Araştırma”. Kahramanmaraş Sütçü İmam Üniversitesi İktisadi ve İdari Bilimler Fakültesi Dergisi, 6(2), 115-130.

Alan, H. ve Fidanboy, C. Ö. (2013). "'Sinizm, Tükenmişlik ve Kişilik İlişkisi: Bilişim Sektörü Çalışanları Kapsamında Bir İnceleme’”. Süleyman Demirel Üniversitesi Sosyal Bilimler Enstitüsü Dergisi , (1), 165-176.

Arslan, E. T. (2012). ' 'Süleyman Demirel Üniversitesi İktisadi ve İdari Bilimler Fakültesi Akademik Personelinin Genel ve Örgütsel Sinizm Düzeyi'’. Doğuş Üniversitesi Dergisi, Cilt 13, Sayı 1, 12-27. 
Aslan Karacaoğlan, F. ve Boylu, Y. (2014). 'Örgütsel Sinizm ve Psikolojik Sözleşme İhlali Arasındaki İlişkiyi Belirlemeye Yönelik Bir Araştırma'. Journal of Recreation and Tourism Research, 1(2), 33-45.

Babadağ, M. (2018). İşe Yabancılaşmanın Sanal Kaytarma Üzerindeki Etkisi. Balıkesir University The Journal of Social Sciences Institute , 21(39), 207-239.

Bacaksız Eşkin, F., Tuna, R. ve Harmancı Seren, A. K. (2018). 'Sağlık Çalışanlarında Performans ve Örgütsel Sinizm İlişkisi: Hemşireler Üzerinde Bir Araştırma'”. ACU Sağlık Biimleril Dergisi , 9(1), 52-58.

Barnes, L. L. (2010). The effects of organizational cynicism on community colleges: Exploring concepts from positive psychology. Doktora Tezi. California: Claremont Graduate University.

Bateman, T. S., Sakano, T. and Fujita, M. (1992). 'Roger, Me, and My Attitude: Film Propaganda and Cynicism Toward Corporate Leadership'. Journal of Applied Psychology, Vol. 77, 771-786.

Bedeian, A. G. (2017). ' 'Critical Moments in Learning: A Teacher's Ultimate Reward and Glory'. Journal of Management Inquiry, 16(4), 408-411.

Bernerth, J. B., Armenakis, A. A., Feild, H. S. and Walker, H. J. (2007). 'Justice, cynicism, and commitment: A study of important organizational change variables". The Journal of Applied Behavioral Science, 43(3), 303-326.

Blanchard, A. L. and Henle, C. A. (2008). 'C Correlates of Different Forms of Cyberloafing: The Role of Norms and External Locus Of Control'. Computers in Human Behavior, (24), 10671084.

Bock, G. W., \& Ho, S. L. (2009). ' Non-work Related Computing (NWRC)'. Communications of the ACM, 52(4), 124-128.

Costa, P. and Zonderman, A. (1986). 'Cynicism and Paranoid Alienation in the Cook and Medley HO Scale'. Psychosomatic Medicine , 48(3), 283-285.

Çakıcı, A. ve Doğan, S. (2014). "Örgütsel Sinizmin İş Performansına Etkisi: Meslek Yüksekokullarında Bir Araştırma'’. Doğuş Üniversitesi Dergisi, 15(1), 79-89.

Çavuşoğlu, S. ve Palamutçuoğlu, B. T. (2017). 'İş Tatmininin Sanal Kaytarma Üzerindeki Etkisi',. Mehmet Akif Ersoy Üniversitesi Sosyal Bilimler Enstitüsü Dergisi, 9(19), 430-444.

Çopur, Z. ve Başkan Atanur, G. (2019). ' Örgütsel Demokrasi ile Örgütsel Sinizm Arasındaki İlişki: Öğretim Elemanları Üzerine Bir Araştırma”. Yükseköğretim Dergisi , 13(1), 1-12.

Dean, J. W., Brandes, P. and Dharwadkar, R. (1998). 'Organizational Cynicism'. The Academy of Management Review, 23(2), 341-352.

Doorn, O. V. (2008). Cyberloafing: A Multi-Dimensional Construct Placed in a Theoretical Framework. Yayınlanmamş Yüksek Lisans Tezi. The Netherlands: Department Industrial Engineering and Innovation Sciences Eindhoven University of Technology.

Eaton, J. A. (2000). A Social Motivation Approach to Organizational Cynicism. Yayınlanmamış Yüksek Lisans Tezi. Toronto: York Üniversitesi.

Erbaş1, A. and Zaganjori, O. (2017). 'Sosyal İzolasyonun Örgütsel Sinizm Üzerindeki Etkisi',. Yönetim ve Ekonomi Dergisi, 24(1), 39-52.

Erdirençelebi, M. ve Yazgan, A. E. (2017). 'Mobbign, Örgütsel Sinizm, Örgütsel Bağlılık ve Bunların Algılanan Çalışan Performansı Üzerine Etkileri'. Süleyman Demirel Üniversitesi İktisadi ve İdari Bilimler Fakültesi Dergisi , 22(2), 267-284.

Erkutlu, H. V. ve Özdemir, H. Ö. (2018). '’Otantik liderlik ve Sanal Kaytarma Arasındaki İlişkide Örgütsel Sinizmin Aracılık Rolü’. Social Science, 13(2), 119-125.

Gökyer, N. ve Türkoğlu, İ. (2018). ' 'Liselerde Görev Yapan Öğretmenlerin Örgütsel Destek Algıları ile Örgütsel Sinizm Tutumları Arasındaki İlişki’’. Eğitim ve Bilim Dergisi, 196(43), 317 340.

Greengard, S. (2000). 'Then High Cost of Cyberslacking'”. Work Force, 79(2), 22-24.

Gün, F. ve Başkan Atanur, G. (2017). ' Öğretim Elemanlarının Algılarına Göre Örgütsel Sinizm ile Tükenmişlik Düzeyleri Arasındaki İlişkinin İncelenmesi’’. Hacettepe Üniversitesi Eğitim Fakültesi Dergisi , 32(2), 361-379. 
Kalağan, G. ve Güzeller, C. O. (2010). 'Öğretmenlerin Örgütsel Sinizm Düzeylerinin İncelenmesi'’. Pamukkale Üniversitesi Eğitim Fakültesi Dergisi, (27), 83-97.

Kaplan, M. ve Çetinkaya, A. Ş. (2014). "Sanal Kaytarma ve Demografik Özellikler Açısından Farklılıklar: Otel İşletmelerinde Bir Araştırma'. Anatolia: Turizm Araştırmaları Dergisi, 25(1), 26-34.

Karataş, A. ve Avcı, S. B. (2017). "Kamu Kurumlarında Sanal Kaytarma Olgusunun Değerlendirilmesi', Süleyman Demirel Üniversitesi İktisadi ve İdari Bilimler Fakültesi Dergisi , 22(15), 2321-2346.

Kerse, G., Soyalın, M. ve Karabey, C. N. (2016). 'Kişi-Örgüt Uyumu, Nötrleştirme ve Algıllanan Yönetici Desteğinin Sanal Kaytarmaya Etkisi: Ampirik Bir Çalışma', Aksaray Üniversitesi Íktisadi ve İdari Bilimler Fakültesi Dergisi, 8(4), 100-113.

Kökalan, Ö. ve Anaş, K. (2016). 'Çalışanların Örgütsel Sinizm Tutumlarının İşe Yabancılaşmaları Üzerine Etkisi: Vakıf Üniversiteleri Üzerine Bir Araştırma'. Bilgi Ekonomisi ve Yönetimi Dergisi , 9(2), 97-109.

Lim, V. K. (2002). 'The it Way of Loafing on the Job: Cyberloafing, Neutralizing and Organizational Justice". Journal of Organizational Behavior , (23), 675-694.

Nafei, W. A. and Kaifi, B. A. (2013). The Impact of Organizational Cynicism on Organizational European Journal of Business and Management , 5(12), 131-147.

Naus, F., Iterson, A. V. and Roe, R. (2007). "'Organizational cynicism:Extending the exit,voice,loyalty,and neglect model of employees' responses to adverse conditions in the workplace ". Human Relations, 60(5), 683-718.

Örücü, E. ve Yıldız, H. (2014). 'İşyerinde Kişisel İnternet veTeknoloji Kullanimi: Sanal Kaytarma". Ege Akademik Bakış Dergisi, 14(1), 99-114.

Reichers, A. E., Wanous, J. P. and Austin, J. T. (1997). ''Understanding and Managing Cynicism About Organizational Change'. Academy of Management Executive, (11), 48-59.

Sawitri, H. S. (2012). 'Role of Internet Experience in Moderating Influence of Work Stressor on'. Procedia-Social and Behavioral Sciences, (57), 320-324.

Shahzad, A. ve Mahmood, Z. (2012). 'The Mediating - Moderating Model of Organizational Cynicism and Workplace Deviant Behavior: (Evidence from Banking Sector in Pakistan)'. Middle East Journal of Scientific Research, 12(5), 580-588.

Sinan , Y. ve Kavas, E. (2016). 'Kurumlarda Örgütsel Sinizm: Karşılaştırmalı Bir Analiz'. Uluslararası Sosyal Araştırmalar Dergisi , 9(44), 1211-1220.

Stern, D., Stone, J. R., Hopkins, C. and McMillion, M. (1990). ' 'Quality of Students' Work Experience and Orientatiton Toward Work'. Youth and Society, 22(2), 263-282.

Ulusoy, H. ve Benli Gültekin, D. (2017). ' Akademisyenlerin Sanal Kaytarma Davranışları: Bir Kamu Üniversitesi Örneği’'. Uluslararast Sosyal Araşttrmalar Dergisi , 10(54), 924-934.

Ünal, Ö. F., Tekdemir, S. ve Yaldızbaş, S. (2015). 'Kamu Çalışanlarının Sanal Kaytarma Amaçları Üzerine Ampirik Bir Araştırma'. Çankırı Karatekin Üniversitesi Sosyal Bilimler Enstitüsü Dergisi, 6(2), 515-534.

Vice, S. (2009). "Cynicism and Morality'. Ethical Theory and Moral Practice, 14(2), 169-184.

Wilkerson, J. M., Evans, W. R. ve Davis, W. D. (2008). 'A Test of Coworkers' Influence on Organizational Cynicism, Badmouthing, and Organizational Citizenship Behavior'. Journal of Applied Social Psychology, 38(9), 2273-2292.

Yağc1, M. ve Yüceler, A. (2016). ' Kavramsal boyutlarıyla sanal kaytarma'. International Journal of Social Sciences and Education Research , 2(2), 531-539.

Yaşar, S. ve Yurdugül, H. (2013). 'The Investigation Of Relation Between Cyberloafing Activities And Cyberloafing Behaviors In Higher Education”. Social and Behavioral Science, (83), 600-604.

Yavuz, A. ve Bedük, A. (2016). 'Örgütsel Sinizm ve Örgütsel Bağlılık Arasındaki İlişki: Bir Kamu Bankasının Konya Şubelerinde Örnek Uygulama’. Selçuk Üniversitesi Sosyal Bilimler Enstitüsü Dergisi, (35), 301-313.

Yazıcıoğlu, İ. ve Gençer Özcan, E. (2017). ‘Örgütsel Adalet Algısının Sinizm Üzerine Etkisi: Devlet Üniversiteleri Meslek Yüksekokullarında Bir Araştırma', İşletme Araştırmaları Dergisi , 9(3), 106-119. 
Yıldırım, F. (2018). ' Tükenmişlik Düzeyinin Sanal Kaytarma Davranışına Etkisinde İş Doyumunun Arac1lık Rolü’. Gazi Üniversitesi Sosyal Bilimler Dergisi, 5(13), 302-313.

Yıldırım, S. K. ve Karabey, C. N. (2017). ' 'Etik İklim ve Örgütsel Kontrol Mekanizmalarının Sanal Kaytarma Davranışı Üzerindeki Etkisinde Örgütsel Sinizmin Aracılık Rolü'’ Gazi Üniversitesi Sosyal Bilimler Dergisi, 4(11), 556-594.

Yıldız, B. ve Yıldız, H. (2015). 'İş Yaşamındaki Sanal Kaytarma Davranışlarının Hukuki Yönden İncelenmesi'’. Yönetim ve Ekonomi Araştırmaları Dergisi, 13(3), 1-17.

\section{SUMMARY}

Even if those who are in the management of the organization try to eliminate all kinds of factors that will negatively affect the performance of their employees, many human-related problems may arise. Examples of these problems are cyberloafing behaviour and organizational cynicism. Innovations on technology and informatics in the developing world affect organizations as well as individuals. However, if this virtual world is not managed well, it may cause negative events. Since the use of the internet becomes easy and it is possible to access the internet via mobile phones, non-business internet uses allow virtual losing behavior. Virtual losing behaviors cause serious efficiency losses in organizations with this aspect. This concept can also contribute to the business life of employees with its other aspect. Organizational cynicism is the negative thoughts of the person which can be seen as a threat. There are many concepts that cause cynicism. The age of the employees in the institution has a regulatory effect on the effect of cynicism on cyberloafing behavior. These are mobbing, ineffectiveness in leadership, injustice in power distribution, poor management, long working hours, performance declines, delay in promotion times, stress, etc. When we consider that organizational cynicism behaviors increase cyberloafing behaviour; it is extremely important to carry out the necessary studies to reduce the cynical behaviors, also known as the development of negative attitudes towards the organization where the employees work. According to the simple linear regression analysis, independent variable cynicism has been found to have a significant effect on dependent variable cyberloafing behaviour. To enable managers to express themselves to reduce their virtual losing behavior, to provide justice within the organization, to direct employees to rotation, etc. recommendations can be given. As a result of the analyzes, it has been concluded that there is a statistically significant relationship between dependent variable virtual slacking and independent variable cynicism and the ages working in the institution, and the age of the organization employees has a significant effect on virtual slacking behavior. Employees who are new to the organization they work for will act with the fear of being unemployed and the sense of putting themselves at the forefront in their jobs, and they will not resort to virtual slacking as much as experienced employees in the business. However, more experienced employees will apply more to virtual slacking behavior by abstracting themselves from internal innovations, with the confidence that working in the same institution for a long time and can do their job better. In this case, managers can be given advice on identifying the underlying causes of the employees' cynical behavior and making efforts to improve. Decreasing cynic behavior will both 
reduce virtual slacking and prevent time wasting. For organizations, it can be stated that productivity and performance may increase if virtual losing and cynicism behavior decrease. According to this study; the effects of cynicism on virtual losing behavior have a regulatory effect on the ages of the employees at the institution and there is a positive and significant relationship between virtual slacking behavior and cynicism. 